\title{
宇宙曝露実験用自立式温度・データ記録器の開発
}

山下雅道 $(I S A S / J A X A) \cdot$ 山下真 $($ 東大 ·院・数理科学 $) \cdot$ 三枝誠行（岡山大・理）

国際宇宙ステーションや回収型衛星での生物学 実験において温度などの実験環境を測定し記録す る記録器を開発した。宇宙機搭載においてどのよう な開発要素があるかを識別したうえ, システムの概 念設計をおこなった。国際宇宙ステーションの曝露 部において生物試料などを長期 $(0.5$ から 2 年) に 宇宙環境に曝露したのち, 地上に回収し生物試料の 生存率や変異を分析したり, 生命関連化学種・物質 も宇宙環境に曝露し, その変性や反応をたしかめる 実験が構想されている。これらの実験は, 生物の極 限環境耐性について宇宙を利用することにより明 らかにするという生物科学ばかりではなく, 宇宙胚 子説の検証や火星など圈外生命探査の対象である 天体を地球起源の生命体で污染する可能性の評価 などに寄与する。惑星起源の生命関連化学種や関連 物質を, 宇宙環境に曝露することにより, いかほど の消長をみせるかを明らかにすることは, 生命の起 源にかかわる重要な設問にこたえるものである。高 い科学的な質の曝露実験を実現するには, 曝露状態 （温度，放射線）を監視し記録する機能を実験シス テムにくわえて曝露履歴を記録し, あるいは妥当な 解析モデルを開発して実測值によりその妥当性を 検証して評価することが求められる。市販の温度・ デー夕記録器を評価したところ, いずれも設定した 仕様をみたすことがなかったので, ワンチップパー ソナルコンピュータにより宇宙用自立式温度・デー 夕記録器を開発することとした。

\section{1. 宇宙用自立式温度・データ記録器の要求仕様}

環境ログは曝露容器中に記録器を収納し, あるい は実験システムに組み込んで実施する。宇宙機のバ スからは電源の供給をうけず，コマンドやデータ のやりとりをおこなわない自立式の記録器とする。 記録器と曝露容器あるいは実験システムの間のイ ンターフェース項目は，1）記録器の物理的な大き さの包絡が曝露容器・実験システムへの収納・取り 出しを可能にする。2) 記録器の機械的支持と, 打 ち上げ帰還時の過重力・振動状態での伝達特性。3) 記録器と曝露容器・実験システムの間の熱的な結合 である。このほかに, 安全性要求に応えるために, 仮に記録器に内藏の電池が障害を起こした場合に, 曝露容器が与圧容器として適合するか, 圧上昇にお
いてリリーフ弁や安全ラプチャー機能を有するか についても考慮する。

これらもふまえて, 記録器への要求仕様を以下の ように規定した。

測定温度範囲: +80 から $-80^{\circ} \mathrm{C}$ 。国際宇宙ステーショ ンの暴露部で想定される最低・最高温度。

動作温度範囲および貯蔵温度範囲 : 測定温度範囲と おなじ

測定精度 $: \pm 1^{\circ} \mathrm{C}$

ログデータ量: デフォルトとして 10 分間隔の測定・ 記録を 1 年以上。軌道上での熱環境の最悪条件(高 温，および低温）は 1 年の間に少なくとも 1 回 ずつは測定して, 熱モデルによるシミュレーショ ンの妥当性を検証する。

プログラムスタート：レイトアクセス時にそれより

最大半年後から測定・記録を開始するように設 定できること。

ワンタイム記録：記録したデー夕に上書きすること なく，測定・記録開始後に一回だけ記録する。

データの不揮発性：ミッション終了時まで時間に内 蔵する電池の容量が不足する場合には, 記録さ れたデー夕が保持され, 回収後に電源を再投入 してそのデータを読み出せること。

物理的大きさ：温度計測記録を計画する生物実験装 置の物理的な包絡のなかにおさまる。

真空環境での動作 : 打ち上げ時および帰還時に経験 する圧力の変動速度は別に規定する。

安全性: 国際宇宙ステーションへの搭載において は，かりに船外に設置されるとしても有人宇宙 機により運搬されることから，そのフェーズに ついての安全性要求仕様は有人システムの基準 を適用する。また船外に設置したフェーズでも 有人システムの安全性に影響を与えないことを 立証する。

信頼性：データの測定・記録機能についての信頼性 要求は $80 \%$ とする。ただし本機器に障害が発生 して, データの記録ができない場合にも，生物 試料への障害影響の伝搬のないこと。

その他の機能 : 測定・記録条件の設定，動作状態の 確認, 記録デー夕の読み出しといった機能を地 上支援装置とのくみあわせにおいて実現する。 


\section{2 システム概念設計}

\section{1 システム構成}

温度・デー夕記録器は次の要素から構成する。

センサー：温度などの環境要素を測定する 記録器回路 : 温度などの環境要素を記録する 電池: 一次電池から記録器回路に電源を供給し, 宇 宙システムから自立した動作を可能にする

与圧容器 : 電池などで与圧する必要のある部品を収 納し与圧する。

このほかに地上支援機器として, 測定・記録条件 の設定と動作状態の確認したり, 測定データを回収 し解析する装置がある。

\section{2 基本概念}

宇宙実験へ適用することから，記録器の設計にお いて以下の項目を検討した。

宇宙放射線の遮蔽：CPU など主要な部分の耐宇宙 放射線機能を高めるために, 適切な厚みの鉛あ るいはタングステンにより遮蔽することは，高 エネルギーの宇宙線が入射したときに核反応に よってシャワーを発生して広範囲に障害を発生 させると推定されることから採用しない。高工 ネルギーの宇宙放射線被爆による論理素子部の 永久故障については許容する。

放射線によるシングルイベントエラーからの復旧： 論理素子部の永久故障とは別に, 放射線の効果 により一時的に論理状態が反転したりするシン グルイベントエラーが発生する。この状態から の復旧のために，定期的に動作をリセットする。 この動作は，リアルタイムクロック素子からの 割り込みによる。

システムの冗長設計 : 不揮発メモリーにおけるパラ メー夕格納領域を物理的にはなれた部分に設定 することが可能な場合には，3つの読み出しデー 夕で多数決をとることを考慮する。ただし CPU 部などを圥長とはしない。必要あればシステム 単位で冗長とする。

低消費電力化：スタンバイ時の消費電流の抑制をさ まざまにはかる。

\section{3 八ードウエアの構成}

試作した温度・デー夕記録器の大きさは $46 \times 35$ $\times 14 \mathrm{~mm}$ で質量は $24 \mathrm{~g}$ であった。ただしこれには 与圧容器をふくまない。またポッティング剤の質量 をふくまない。

\subsection{1 記録器の構成チップの選定} 記録器の電子回路素子はつぎの 4 つを選んだ。

ワンチップマイクロコンピュータ：H8/3664（ルネ サス) A/D 変換, シリアルポート, $\mathrm{I}^{2} \mathrm{C}$ バスイン ターフェースを有する素子であり, 動作制御プ ログラムを内蔵するリードオンリーメモリに書 き込んで使用する。スタンバイ・モードに遷移 させると消費電力を抑制することができる。低 電力消費ということではさらにすぐれたチップ も利用できる。

リアルタイムカウンター (RTC): RTC-8564NB（エ プソン）をもちいた。年月日時刻のデータを $\mathrm{I}^{2} \mathrm{C}$ バスに出力する。アラーム割り込みを発し, ワ ンチップマイクロコンピュータの動作をリセッ トする。

シリアル・電気的消去可能プログラマブル・ リードオンリーメモリー (EEPROM) : $1 \mathrm{Mbit}$ AT24C1024 (Atmel) をもちいた。 I ${ }^{2} \mathrm{C}$ バスにつな いでデー夕を読み書きするメモリー素子で，1 チップで 13 万バイト記録可能であり, 電源が断 してもデー夕を保持できる。記録デー夕数はお よそ 64,000 が可能であり, 10 分間隔で 1 年以上 記録することができる。(市販記録器の 2 倍)

アナログ・スイッチ：スタンバイ状態でセンサー への電流を遮断する素子でありワンチップマイ クロコンピュータによりオンオフを制御する。 ADG701 (Analog Devices)をもちいた。

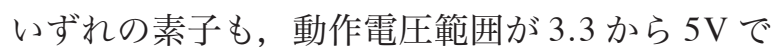
あるものを選択した。宇宙放射線環境下での素子の 特性については，無人宇宙実験システム研究開発機 構により調査されているので参考になる。ただし, リアルタイムカウンターおよびアナログ・スイッチ については，このような参考データがない。

\subsection{2 センサー}

サーミスタと熱電対について比較したところ，つ ぎのような評価から, 測定精度に格段の要求がない かぎり，サーミス夕を感温素子としてもちいること が適当であることがわかった。

熱電対：信号出力が熱電対アンプによれば要求測 定温度範囲においてリニアである。熱電対信号 の変換 IC 素子である AD595 (アナログデバイス) はカタログ仕様として動作温度範囲が $-55^{\circ} \mathrm{C}$ か ら $+125^{\circ} \mathrm{C}$ と規定されているが, $-85^{\circ} \mathrm{C}$ でも動作 することを確認した。しかし，急速にこの IC 素 子の温度が変化するときに, 熱電対信号のゼロ 
点補償がうまく機能しない。また熱電対アンプ 素子には $\pm 3.4 \mathrm{~V}$ 以上の 2 電源を供給することが 必要である。

サーミス夕：抵抗変化が対数的であるために, 温度 測定の精度が測定温度範囲で一様ではない。素 子の動作温度についての仕様は $-80^{\circ} \mathrm{C}$ まではの びていないため, センサーの温度サイクル耐性 を評価する必要がある。

\subsection{3 電源}

記録器を動作させる電池には，宇宙でも使用実績 があり，もっとも低い温度まで動作可能な一次電 池である塩化チオニル・リチウム電池を採用する。 その電流容量の要求を規定するために, 記録器回 路の消費電流を実測した。温度測定時には，0.2 秒 のあいだ $15 \mathrm{~mA}$ を消費する。そのほかのスタンバ イ状態では $10 \mu \mathrm{A}$ (供給電圧 $5 \mathrm{~V}$ ) であり, これは それぞれの素子のカタログ予測值：EEPROM; $6 \mu \mathrm{A}$, $\mathrm{H} 8$ (standby); $5 \mu \mathrm{A}, \mathrm{RTC} ; 0.33 \mu \mathrm{A}$ の和と合致する。

1 年間 10 分おきに計測・記録すると, 消費する 電流容量は 0.13 A Hour と推定できる。一次電池の 低温および大きな温度サイクルでの実効的な電流 容量や性能劣化を考慮し, 電流容量が 10 倍の 1.3 $\mathrm{A} \mathrm{H}$ 以上の性能をもつ電池を選択することとした。

一次電池で $\pm 80^{\circ} \mathrm{C}$ の温度条件で使用実績のある のは塩化チオニル・リチウム電池である。SAFT 社
の電池は $-80^{\circ} \mathrm{C}$ に対応し, 宇宙応用の実績も ESA などにおいてある。ただし，カタログに掲載され ている市販品は $-60^{\circ} \mathrm{C}$ までである。BiPOWER 社の 電池はカタログ仕様では $-55^{\circ} \mathrm{C}$ が下限だが, 市販 の温度記録器 (MadgeTech) にくみこまれた例では, $-86^{\circ} \mathrm{C}$ までの使用実績がある。一方, 使用温度の上 限は $+80^{\circ} \mathrm{C}$ である。

検討すべき項目は，真空環境動作であり，大電流 が流れた際の安全性要求をみたすために，電池には ラプチャーディスクがもうけられ，1気圧の圧力差 で破裂する。電池のなかの電解液は塩化チオニル $\left(\mathrm{SOCl}_{2}\right)$ で腐食性が強く, 毒性もある。仮に衝撃な どで電池からもれた塩化チオニルは，大気中では $\mathrm{H}_{2} \mathrm{O}$ と反応し $\mathrm{HCl}$ と $\mathrm{SO}_{2}$ (亜硫酸ガス) を生成する。

宇宙用温度・デー夕記録器の安全性対応は, 与圧 容器のなかに電池を収納し, 過電流を防止して漏 出したガスに耐性のある物質を用いることとする。 塩化チオニルに対応できるポッティング材も, 過去 には開発されたことがある。

電源回路としてチャージアップポンプあるいは DC/DC 変換回路を用いるかについては，アナログ アンプを用いるときにプラス・マイナスの電源を要 すること, 電池の出力電圧が低温で低下する可能性 のある場合に考慮するメリットがある。また, 温度 スイングが付加されたときに電池出力電圧が大き

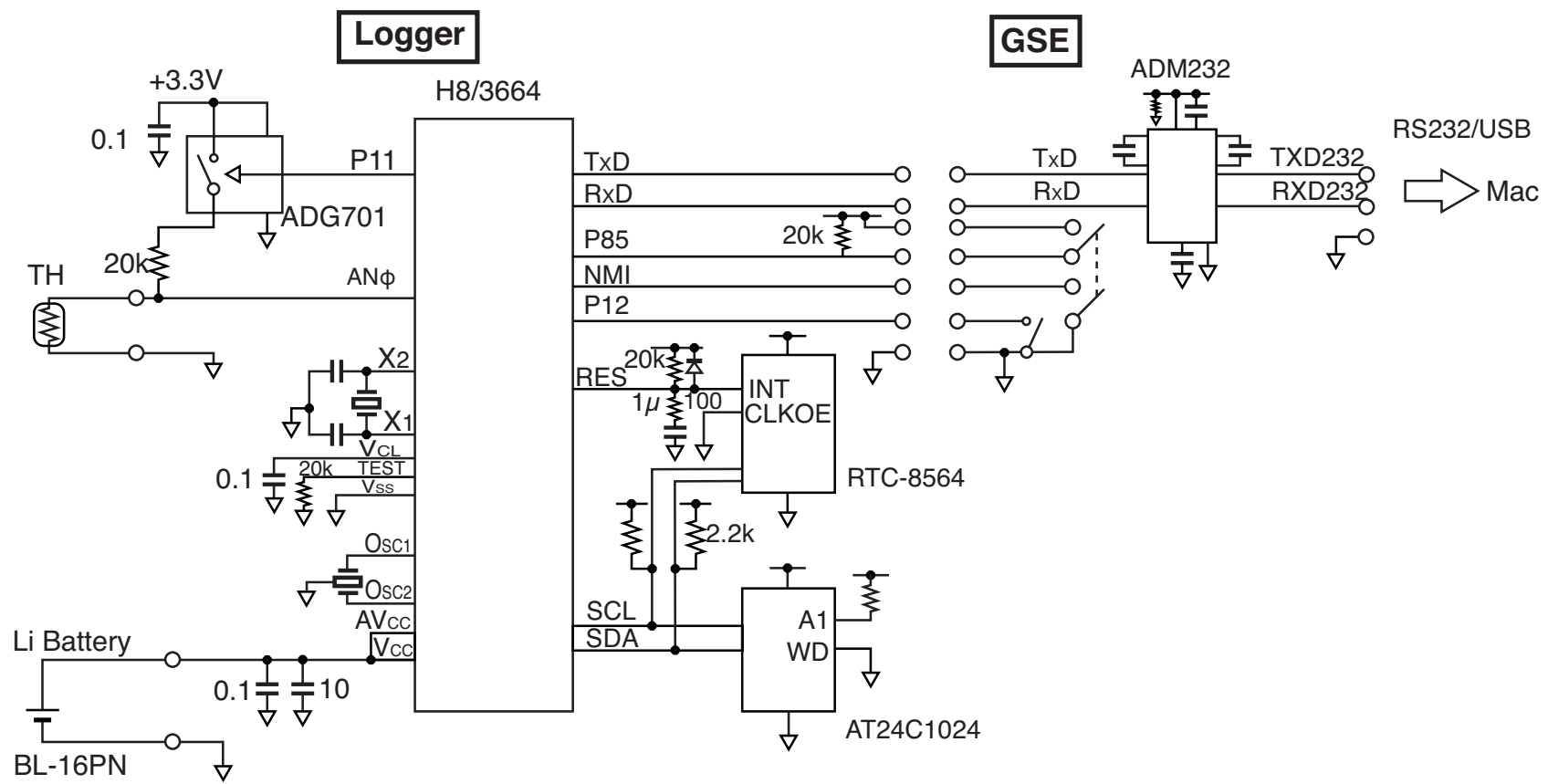

Fig. 1. Circuit Diagram of the Temperature / Data Logger 


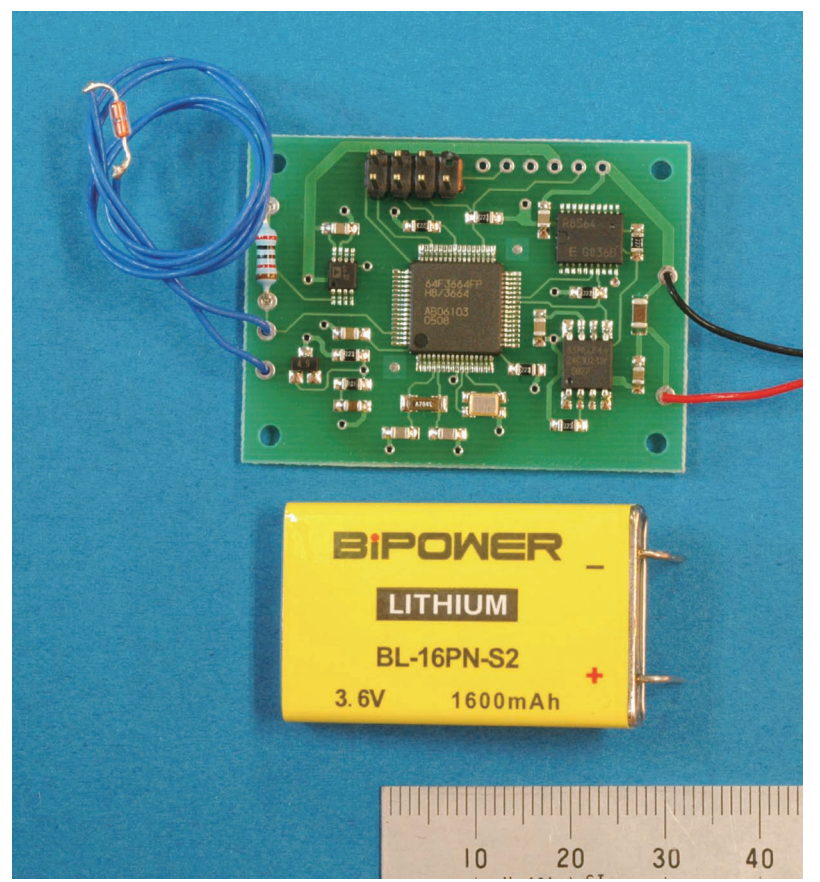

Fig. 2. Print Cuircuit Board and Li Battery of the Temperature / Data Logger

く変動し, CPU の不定動作により EEPROM のデー 夕に上書きするリスクの判定が必要である。

\section{4 ソフトウエアの構成と概要}

温度・デー夕記録器の動作を制御するソフトウェ アは Mac OS-X上でC 言語により開発し，H8 ワ ンチップマイクロコンピュータの内蔵リードオン リーメモリーに格納した。その構成と概要は以下の 通りである。

初期化 :

リアルタイマーカウンターによる定期的（デフォ ルト：10 分）なリセットによりこの初期化ルーチ ンが起動される）IO ポートの入出力をそれぞれの ポートについて設定し，温度デー夕を入力する A/D 変換ポートを指定して，その条件を設定する。プロ グラム動作のタイミング制御にもちいるタイマー カウンタのクロックや割り込み $(10 \mathrm{~ms})$ の条件を きめる。リアルタイムカウンタの動作条件をきめ る。記録条件を設定したり, あるいは記録したデー 夕を送出するためのシリアルポートについてビッ トレートなどの通信のパラメータを設定する。ス リープ動作を設定したうえで，サブスリープモード へ移行する。

メインルーチン :

動作モードをきめるために IO ポートの一つを入
力し，そのビットにしたがって 0 ならログモード, 1 なら設定モードとする。

ログモードでは，サーミスタに電流をながすアナ ログスイッチをオンし, 状態が落ち着くのをまっ て, 温度デー夕を $\mathrm{A} / \mathrm{D}$ 変換する。2 バイトのデー夕 に編成した上で, EEPROMにデー夕格納し，格納 場所を示すポインタを進める。その後，サブスリー プ状態に遷移させて消費電力を低下させる。

設定モードでは，シリアルでコマンドをうけるた めのループをまわし, シリアルでコマンドの受信が 終了したらコマンド処理して，その後スリープ状態 に遷移する。サブスリープモードからは，シリアル 受信で復帰する。

コマンド処理の項目は, リアルタイムカウンタ （RTC）レジス夕設定（アドレス\#，データ \% \%), RTCレジス夕取得, 送信（アドレス\#\#）, RTCを 一定時間ごとに/INT 端子のレベルを下げる(リセッ 卜割り込み）ように設定，EEPROM 書き込み（ア ドレス\#\#"", データ\%\%), EEPROM デー夕取得, 送信（アドレス\#\#\#\#， EEPROM データブロック 取得 (先頭アドレス \#\#\#, 長さ $\% \% \% \%$ ), $\mathrm{AD}$ 変 換デー夕取得，送信である。

このほかに, 支援機能としてマックをもちいて, パラメータ・デー夕の送受信, デー夕の編成, デー 夕の変換・表示の機能を C 言語により開発した。

\section{3 搭載性検討のための試験・検証計画}

試作した温度・デー夕記録器は, 基本的な要求 仕様項目のうち，プログラムスタート以外につい ては，その機能を実証することができた。ただし， 実際に宇宙実験に適用するには，次にあげるいくつ かの検討・試験項目がのこっている。

打ち上げ，帰還環境への適合性について，機械環 境試験（振動, 衝撃）計画を立案して実施しなく てはならない。打ち上げ, 鹵還時の振動・衝撃試 験条件をきめ, 曝露システムや生物試料収納容器 を製作して記録器をくみこみ試験する必要がある。 評価項目は, 記録器の機能が健全に保たれること, 記録条件のリセットなどの障害の発生する確率が 十分に低いこと, 生物試料収納容器を物理的に壊さ ないことである。

低温下の動作試験および熱サイクル $\left(+80^{\circ} \mathrm{C}\right.$ から $\left.-80^{\circ} \mathrm{C}\right)$ を負荷して, 記録周期, 記録予約開始時刻, 温度遷移状態での温度測定記録の正確性をたしか める。熱サイクル試験では, 電池のハーメチック シールや電子素子のパッケージ，ポッティングした プリント回路板とハンダ付け部を詳細に検査して, 
ヒビそのほかの発生の有無を検査し, 回路機能が維 持されていることを確認する。電池容量の劣化も重 要な評価項目である。熱サイクル試験においては, 電池容量が低下した際に, 電池電圧が回路の動作電 圧範囲より低下したりまた復帰したりするかをよ くしらべる。そのような電源電圧変動をマイクロコ ンピュータにあたえて，記録済みのデータが上書き されないかを確かめることは，宇宙実験での温度・ デー夕記録器の運用についての制約を規定するた めに重要である。

与圧容器については漏れ速度および真空に曝露 した際の変形や内部の回路基板や電池にかかる応 力をよく検査することが求められる。振動，衝撃を 負荷して記録器の機能が維持されるかも重要な試 験項目である。
記録器のポッティング剤などからの出ガスにつ いて調べておくことは，記録器の生物適合性を評価 する上でかかせない。高温真空状態に記録器を曝露 した際の出ガスの成分が，生物試料の特性，生存蘇 生率に有意な影響を及ぼさないこと。出ガス成分の 分析に加え，使用材料から想定される出ガス成分に ついて生物適合性を試験する。出ガスについては, シリコン樹脂のポッティング剂からの低分子シロ キサンなどが想定される。安全性については，その 要求を識別して，必要な設計，試験について規定す る。現段階の識別項目は電池である。安全性要求か ら付加すべき回路やそのほかの機構について明ら かにする。

\title{
Stand-Alone Temperature / Data Logger for Space Exposure Experiment
}

\author{
Masamichi Yamashita ${ }^{1}$, Makoto Yamashita ${ }^{2}$, Masayuki Saigusa $^{3}$ \\ ${ }^{1}$ Institute of Space and Astronautical Science, JAXA, Sagamihara, 229-8510, Japan. yamashita@surc.isas.jaxa.jp \\ ${ }^{2}$ Graduate School of Mathematical Sciences, University of Tokyo, Komaba, Tokyo, 153-8914, Japan. \\ ${ }^{3}$ Faculty of Science, Okayama University, Tsushima, Okayama, 700-8530, Japan.
}

\begin{abstract}
A stand-alone data logger was developed for biological exposure experiment in space. A combibnation of one chip micro computer with electrically erasable programabble read only memory, real timer counter and analog awitch enables measurement of temperature every 10 minutes (default) for a period of one year at electric power supplied from lithium primary battery. It can be operated under thermal swing between -80 and $+80{ }^{\circ} \mathrm{C}$, expected during expoosure on outer environemnt of the International Space Station or biological orbiting satellites. Physical size and mass of the prototype logger are $46 \times 35 \times 14 \mathrm{~mm}$ and $24 \mathrm{~g}$ (not including potting material coated over the circuit board nor a pressurized container for the logger).
\end{abstract}

